\title{
Limits on Limitations: The Essence of Fundamental Rights in the EU
}

\author{
Koen Lenaerts*
}

(Received 01 May 2019; accepted 30 May 2019)

\begin{abstract}
The concept of the essence of a fundamental right - set out in Article 52(1) of the Charter of Fundamental Rights of the European Union (the "Charter")—operates as a constant reminder that our core values as Europeans are absolute. In other words, they are not up for balancing. As the seminal judgment of the Court of Justice of the European Union (the "CJEU") in Schrems shows, where a measure imposes a limitation on the exercise of a fundamental right that is so intense and so comprehensive that it calls into question that right as such, that measure is incompatible with the Charter, as it deprives the right at issue of its essence. This is so without the need for a balancing exercise of competing interests, because a measure that compromises the very essence of a fundamental right is automatically disproportionate. Therefore, the present contribution supports the contention that in order for the concept of essence to function in a constitutionally meaningful way, both EU and national courts should apply the "respect-for-the-essence test" before undertaking a proportionality assessment.
\end{abstract}

Keywords: Essence of fundamental rights; proportionality; horizontal direct effect; Charter of Fundamental Rights of the European Union; Court of Justice of the European Union

\section{A. Introduction}

Respect for the essence of fundamental rights is laid down in Article 52(1) of the Charter of Fundamental Rights of the European Union (the "Charter"), as one of the conditions that must be fulfilled in order for a limitation on the exercise of a fundamental right to be justified. ${ }^{1}$ Accordingly, where an EU measure fails to take due account of the essence of a fundamental right, that measure is incompatible with the Charter and must be annulled or declared invalid. ${ }^{2}$ Similarly,

${ }^{\star}$ President of the Court of Justice of the European Union and Professor of European Union Law, Leuven University. All opinions expressed herein are personal to the author. This contribution is based on the Opening Address that I delivered on the occasion of the conference entitled “The Essence of EU Fundamental Rights", that took place on May 17-18, 2018, at the Institute for European Law, Leuven University.

${ }^{1}$ Article $52(1)$ of the Charter reads as follows:

Any limitation on the exercise of the rights and freedoms recognized by this Charter must be provided for by law and respect the essence of those rights and freedoms. Subject to the principle of proportionality, limitations may be made only if they are necessary and genuinely meet objectives of general interest recognized by the Union or the need to protect the rights and freedoms of others.

Charter of Fundamental Right of the European Union, Oct. 26, 2012, 2012 O.J. (C 326) 44 (emphasis added) [hereinafter The Charter]. See Armin von Bogdandy et al., Reverse Solange-Protecting the Essence of Fundamental Rights Against EU Member States, 49 Common Mkт. L. Rev. 489, 510 (2012) (noting that Article 2 of the Treaty on European Union ("TEU”) aims at safeguarding the essence of fundamental rights).

${ }^{2}$ ECJ, Case C-362/14, Schrems v. Data Protection Commissioner, ECLI:EU:C:2015:650, Judgment of 8 October 2015. 
where a national measure implementing EU law-within the meaning of Article 51(1) of the Charter-fails to respect the essence of a fundamental right, that measure is to be set aside.

The concept of the essence of a fundamental right is not new but can be traced back to the 1949 German Basic Law (the "Wesensgehalt"), which, in turn, influenced the incorporation of that concept into the constitutions of other Member States, such as Portugal ("conteúdo essencial"), ${ }^{4}$ Spain (“contenido esencial"), ${ }^{5}$ Poland (“istota"), ${ }^{6}$ Estonia ("olemus"), ${ }^{7}$ Hungary ("lényeges tartalom"), ${ }^{8}$ the Czech Republic ("podstata"), ${ }^{9}$ Slovakia ("podstata"), ${ }^{10}$ and Romania ("existența"). ${ }^{11}$ Therefore, the reason why that concept found its way into the Charter may be, as some scholars have suggested, that it stems from the constitutional traditions common to the Member States. ${ }^{12}$

In the same way, although the obligation to respect the essence of a fundamental right is not expressly recognized in the European Convention on Human Rights (the "ECHR"), it can nevertheless be found in the case law of the European Court of Human Rights (the "ECtHR"). ${ }^{13}$

At the EU level, the Explanations relating to Article 52(1) of the Charter indicate that the concept of the essence of a fundamental right is based on the case law of the Court of Justice of the European Union (the "CJEU") on the protection of fundamental rights, understood as general principles of EU law. Those Explanations quote a passage of the judgment of the CJEU in Karlsson, decided in 2000, where that Court held that a limitation on the exercise of a fundamental right may be justified, provided that it pursues an objective recognized as legitimate by the EU legal order and does not "constitute, with regard to the aim pursued, disproportionate and unreasonable interference undermining the very substance of [that right] ..."14 In that passage, the CJEU cites paragraph 18 of its previous judgment in Wachauf, ${ }^{15}$ decided in 1989. Even more so, one can find that same passage in judgments going back as far as Hauer, decided in $1979 .{ }^{16}$ Subsequently, other judgments have also reproduced the passage quoted in

\footnotetext{
${ }^{3}$ GRUNDGESETZ [GG] [BASIC LAw], art. 19(2), translation at http://www.gesetze-im-internet.de/englisch_gg/index.html.

${ }^{4}$ Constitución de la República Portuguesa, 1976, art. 18(3) (Port.).

${ }^{5}$ C.E., B.O.E. n. 53(1), Dec. 29, 1978 (Spain).

${ }^{6}$ Konstytucja Rzeczypospolitej Polskiej [KRP] [Constitution] Apr. 2, 1997, art. 31(3) (Pol.).

${ }^{7}$ Eesti Vabaritgi Póhiseadus [EVP] [Constitution] June 28, 1992, art. 11 (Est.).

${ }^{8}$ Magyarország Alaptörvénye [The Fundamental Law of Hungary], Alaptörvény, art. I(3).

${ }^{9}$ In the Czech Republic, the catalogue of fundamental rights is not in the Constitution itself but in the Charter of Fundamental Rights and Basic Freedoms (the "C-S Charter") adopted by the extinguished Czechoslovak Federative Republic. Nevertheless, that Charter enjoys constitutional status in the Czech Republic. See ÚsTAVA ČESKÉ REPUBLIKY [UCR] [Constitution] Dec. 16, 1992, art. 3 (Czech Republic); Listina Základních Práv a Svobod [Charter of FundAMENTAL RightS AND BASIC FrEedoms] 1991, art. 4(4) (Czech).

${ }^{10}$ See Ústava Slovenskej Republiky [USR] [COnstitution] Sept. 1, 1992, art. 13(4) (Slovk.) (reproducing, in essence, Article 4(4) of the C-S Charter).

${ }^{11}$ Constituția României [CR] Nov. 21, 1991, art. 53(2) (Rom.).

${ }^{12}$ See, e.g., Tuomas Ojanen, Making the Essence of Fundamental Rights Real: The Court of Justice of the European Union Clarifies the Structure of Fundamental Rights under the Charter, 12 EuR. Const. L. REv. 318, 323 (2016); Maja Brkan, The Concept of Essence of Fundamental Rights in the EU Legal Order: Peeling the Onion to its Core (2018) 14 EUR. CONST. L. REV. 332, 338 (2018).

${ }^{13}$ ECtHR, Judgment of 23 July 1968, Belgian Linguistic Case, CE:ECHR:1968:0723JUD000147462, \$5; Judgment of 27 Aug. 1991, Philis v. Greece, CE:ECHR:1991:0827JUD001275087, \$ 59; Judgment of 12 July 2001, Prince Hans-Adam II of Liechtenstein v. Germany, CE:ECHR:2001:0712JUD004252798, \$44. More recently, see ECtHR, Judgment of 23 June 2016, Baka v. Hungary, CE:ECHR:2016:0623JUD002026112, § 121; Judgment of 8 Nov. 2016, Naku v. Lithuania and Sweden, CE:ECHR:2016:1108JUD002612607, §95; Judgment of 29 Nov. 2016, Lupeni Greek Catholic Parish and Others v. Romania, CE:ECHR:2016:1129JUD007694311, §20.

${ }^{14}$ ECJ, Case C-292/97, Karlsson and Others, ECLI:EU:C:2000:202, Judgment of 13 Apr. 2000, para. 45 (emphasis added).

${ }^{15}$ ECJ, Case C-5/88, Wachauf v. Bundesamt für Ernährung und Forstwirtschaft, ECLI:EU:C:1989:321, Judgment of 13 July 1989, para. 18.

${ }^{16}$ ECJ, Case C-44/79, Hauer v. Land Rheinland-Pfalz, ECLI:EU:C:1979:290, Judgment of 13 Dec. 1979, para. 23.
} 
the Explanations, ${ }^{17}$ even after the entry into force of the Treaty of Lisbon and thus of the Charter. ${ }^{18}$

It is true that there might appear to be a semantic difference between the expression "the very substance of a fundamental right" and that of "the essence" of such a right, laid down in Article 52(1) of the Charter. Nevertheless, as the EU General Court (the "GC") has noted, both expressions may be used interchangeably. ${ }^{19}$ The judgment of the CJEU in Fries also appears to confirm that observation. ${ }^{20}$

Moreover, there are cases pre-dating the entry into force of the Charter where one may argue that the CJEU found, albeit implicitly, that the EU or national measure in question did not respect the essence of the fundamental right at issue. This point can be illustrated by reference to cases such as Johnston or Kadi I where the measures in question were deemed to be immune from judicial review, thereby depriving the persons concerned of any meaningful access to justice. ${ }^{21}$

Against that background, it seems that the concept of the essence of a fundamental right must be examined in the light of the constitutional traditions common to the Member States, the ECHR - as interpreted by the ECtHR - and the case law of the CJEU. In order to carry out that examination, the present contribution is structured as follows. In Part B, it is argued, in the light of the seminal judgment of the CJEU in Schrems, ${ }^{22}$ that the concept of the essence of a fundamental right implies that every fundamental right has a "hard nucleus" that guarantees to each and every individual a sphere of liberty that must always remain free from interference. That nucleus is, in my view, absolute in so far as it may not be subject to limitations. ${ }^{23}$ Once it is established that the essence of a fundamental right has been compromised, the measure in question is incompatible with the Charter. This is so without it being necessary to engage in a balancing exercise of competing interests. As the Schrems judgment shows, a measure that compromises the essence of a fundamental right is automatically disproportionate. Nevertheless, the fact that a measure respects the essence of a fundamental right does not automatically mean that it complies with the principle of proportionality, as the judgments of the CJEU in Digital Rights Ireland and Tele2 Sverige illustrate. ${ }^{24}$ This shows that the respect-for-the-essence test and a proportionality assessment are two different types of inquiry. Part $\mathrm{C}$ examines a different aspect of the essence of fundamental rights, namely, whether the essence of a fundamental right may be relied upon in a dispute between private parties with a view to setting aside conflicting national measures. In that regard, a distinction will be drawn between fundamental rights that may, as a whole, produce horizontal direct effect and those whose horizontal application is limited to the scope of their essence. Finally, in Part D, a brief conclusion supports the view that the concept of the essence of a fundamental right

\footnotetext{
${ }^{17}$ See, e.g., ECJ, Joined Cases 20 \& 64/00, Booker Aquacultur Ltd. and Others v. The Scottish Ministers, ECLI:EU: C:2003:397, Judgment of 10 July 2003, para. 68.

${ }^{18}$ See, e.g., ECJ, Case C-544/10, Deutsches Weintor eG v. Land Rheinland-Pfalz, ECLI: EU:C:2012:526, Judgment of 6 Sept. 2012, para. 54; ECJ, Case C-190/16, Fries v. Lufthansa CityLine GmbH, ECLI:EU:C:2017:513, Judgment of 5 July 2017 , para. 73.

${ }^{19}$ GC, Case T-187/11, Trabelsi and Others v. Council, ECLI:EU:T:2013:273, Judgment of 28 May 2013, para. 81; GC Case T-256/11, Ezz and Others v. Council, ECLI:EU:T:2014:93, Judgment of 27 Feb. 2014 para. 200 (holding that "the 'essential content,' that is, the substance, of the right or freedom at issue must not be impaired").

${ }^{20}$ See Fries, Case C-190/16 at paras. 72-75.

${ }^{21}$ ECJ, Case C-222/84, Johnston v. Chief Constable of the Royal Ulster Constabulary, ECLI:EU:C:1986:206, Judgment of 15 May 1986; ECJ, Joined Cases 402 \& 415/05 P, Kadi and Al Barakaat Int'l Found. v. Council of the Eur. Union et al, ECLI:EU: C:2008:461, Judgment of 3 Sept. 2008.

${ }^{22}$ Schrems, Case C-362/14.

${ }^{23}$ Takis Tridimas, The Principle of Proportionality, in Oxford Principles of European Union Law. Volume I: The European Union Legal Order 243, 256-57 (Robert Schütze \& Takis Tridimas eds., 2018).

${ }^{24}$ ECJ, Joined Cases 293 \& 594/12, Digital Rights Ireland Ltd. v. Minister for Commc'ns, ECLI:EU:C:2014:238, Judgment of 8 Apr. 2014; ECJ, Joined Cases 2013 \& 698/15, Tele2 Sverige AB v. Post-och telestyrelsen and Others, ECLI:EU:C:2016:970, Judgment of 21 Dec. 2016.
} 
operates as a constant reminder that our core values as Europeans are absolute and, as such, are not up for balancing. ${ }^{25}$

\section{B. The Essence of a Fundamental Right in the Light of the Schrems Judgment \\ 1. The Judgment of the CJEU in Schrems}

In Schrems, the CJEU for the first time declared invalid an EU measure on the ground that it did not respect the essence of two fundamental rights, namely, the right to respect for private life and the right to effective judicial protection. ${ }^{26}$ That case concerned a preliminary reference made by the High Court of Ireland in which that court questioned the validity of Commission Decision 2000/520 (the "Commission Decision") providing that personal data could be transferred from the EU to the United States on the basis that the safe harbor privacy principles applicable to organizations established in the U.S. ensured an adequate level of protection of these data. ${ }^{27}$

After holding that the expression "adequate protection," within the meaning of Directive $95 / 46,{ }^{28}$ was to be interpreted as meaning that such transfer could only take place where the US legal order offered an "essentially equivalent protection" to that guaranteed under EU law, the CJEU observed that the Commission Decision permitted US public authorities, notably the NSA, to have access, on a generalized basis, to the content of incoming electronic communications from across the Atlantic. ${ }^{29}$ Such access was found to constitute such a serious and intrusive breach of the fundamental right to respect for private life guaranteed by Article 7 of the Charter, that it compromised the very essence of that right. ${ }^{30}$ In the same vein, the Commission Decision did not refer to the existence of "any possibility for an individual to pursue legal remedies in order to have access to personal data relating to him, or to obtain the rectification or erasure of such data." ${ }^{31}$ Accordingly, the CJEU found that the contested decision did not respect the essence of the fundamental right to effective judicial protection, as enshrined in Article 47 of the Charter. ${ }^{32}$

\section{Three Direct Implications}

In my view, one may draw three direct inferences from that judgment. First, it makes clear that a measure that compromises the essence of a fundamental right may not be justified on any ground, not even where the national security of a third country is at stake. The judgment of the CJEU in Schrems sends a clear message to the EU political institutions to the effect that they may only adopt measures that respect the essence of the fundamental rights in question. In practical terms,

\footnotetext{
${ }^{25}$ Some scholars argue that not all fundamental rights questions should be answered by having recourse to a balancing exercise. See, e.g., Vicki Jackson, Being Proportional About Proportionality, 21 Const. CommENT. 803, 803-59 (2004); Basak Cali, Balancing Human Rights? Methodological Problems with Weights, Scales and Proportions, 29 HUM. RTs. Q. 251, 251-70 (2007); Stavros Tsakyrakis, Proportionality: An Assault on Human Rights? 7 INT'L J. Const. L. 468, 468-93 (2009).

${ }^{26}$ Prior to that judgment, the CJEU had already examined whether the contested EU measure respected the essence of the fundamental rights at issue. In those cases, it found that the EU measure did so. See, e.g., ECJ, Case C-283/11, Sky Österreich GmbH v. Österreichischer Rundfunk, ECLI:EU:C:2013:28, Judgment of 22 Jan. 2013, para. 49; ECJ, Case C-291/12, Schwarz v. Stadt Bochum, ECLI:EU:C:2013:670, Judgment of 17 Oct. 2013, para. 39.

${ }^{27}$ Commission Decision 2000/520, of 26 July 2000 Pursuant to Directive 95/46/EC of the European Parliament and of the Council on the Adequacy of the Protection Provided by the Safe Harbour Privacy Principles and Related Frequently Asked Questions Issued by the US Department of Commerce, 2000 O.J. (L 215) 7 (EC).

${ }^{28}$ See Directive 95/46, of the European Parliament and of the Council of 24 October 1995 on the Protection of Individuals with Regard to the Processing of Personal Data and on the Free Movement of Such Data, 1995 O.J. (L 281) 31 (EC), repealed by Regulation 2016/679, of the European Parliament and of the Council of 27 April 2016 on the Protection of Natural Persons with Regard to the Processing of Personal Data and on the Free Movement of Such Data, 2016 O.J. (L 119) 1 (EU).

${ }^{29}$ Schrems, C-362/14 at paras. $94-97$.

${ }^{30} I d$. at para. 94 .

${ }^{31} I d$. at para. 95

${ }^{32} I d$.
} 
this means that the new Commission decision authorizing the transfer of data from the EU to the United States-in accordance with the privacy shield principles-must also leave untouched the essence of the fundamental right to privacy. ${ }^{33}$ In addition, Schrems highlights the fact that the rights attached to the status of EU citizenship are to be distinguished from the fundamental rights recognized by the Charter. ${ }^{34}$ The reason is that, whilst public security and public policy grounds may justify measures depriving EU citizens of the genuine enjoyment of the substance of the rights conferred by virtue of that status, ${ }^{35}$ the same does not hold true regarding measures depriving a fundamental right of its essence.

Moreover, the finding that a measure that compromises the essence of a fundamental right may not be justified on any ground was recently confirmed by the seminal judgment of the CJEU in Minister for Justice and Equality (Deficiencies in the system of justice). ${ }^{36}$ In that case, the question that arose was whether the executing judicial authority could - exceptionally-refrain from giving effect to a European Arrest Warrant, where such execution would give rise to a real risk of breaching an individual's fundamental right to an independent tribunal and, therefore, his fundamental right to a fair trial as laid down in Article 47 of the Charter. ${ }^{37}$ The CJEU replied in the affirmative. In what is, for present purposes, the most important passage of that judgment, it ruled that:

[T] he requirement of judicial independence forms part of the essence of the fundamental right to a fair trial, a right which is of cardinal importance as a guarantee that all the rights which individuals derive from EU law will be protected and that the values common to the Member States set out in Article 2 TEU, in particular the value of the rule of law, will be safeguarded. ${ }^{38}$

Accordingly, free movement of judicial decisions may be limited where the national court, which issues a warrant that is to be recognized and enforced in other Member States, is not independent, because that lack of independence compromises the very essence of the right to a fair trial.

Second, in respect of fundamental rights that are absolute, such as human dignity, the right to life, the prohibition of torture, and the prohibition of inhuman or degrading treatment, ${ }^{39}$ one may argue that, since no limitation may be imposed upon those rights, their content and their essence are, in effect, coterminous. That may explain why in joined cases Aranyosi and Căldăraru, as well as in the C.K. case, the CJEU ruled that once it is established that the execution of a European Arrest Warrant or the transfer of an asylum seeker runs the risk of subjecting the person concerned to inhuman or degrading treatment, the principle of mutual trust may not be interpreted as requiring such execution or such transfer. ${ }^{40}$ Similarly, that is also why the CJEU held in Abdida, MP and Petruhhin that Articles 4 and 19(2) of the Charter prohibit the expulsion of a

\footnotetext{
${ }^{33}$ See Commission Implementing Decision 2016/1250, of 12 July 2016 Pursuant to Directive 95/46/EC of the European Parliament and of the Council on the Adequacy of the Protection Provided by the EU-U.S. Privacy Shield, 2016 O.J. (L 207) 1 (EU); ECJ, Case C-311/18, Facebook Ireland and Schrems (pending).

${ }^{34}$ See Koen Lenaerts \& Jose A. Gutiérrez-Fons, Epilogue on EU Citizenship: Hopes and Fears, in EU CITIZENSHIP AND Federalism: The Role of Rights 751-81 (Dimitry Kochenov ed., 2017). But see von Bogdandy, supra note 1, at 512.

${ }^{35}$ ECJ, Case C-304/14, Sec'y of State for the Home Dept. v. CS, ECLI:EU:C:2016:674, Judgment of 13 Sept. 2016, paras. 3450; ECJ, Case C-165/14, Rendón Marín v. Administración del Estado, ECLI:EU:C:2016:675, Judgment of 13 Sept. 2016 , paras. 81-87.

${ }^{36}$ ECJ, Case C-216/18 PPU, Minister for Justice and Equal., ECLI:EU:C:2018:586, Judgment of 25 July 2018.

${ }^{37} I d$. at para. 47.

${ }^{38} \mathrm{Id}$. at para. 48 .

${ }^{39}$ ECJ, Case C-112/00, Schmidberger v. Austria, ECLI:EU:C:2003:333, Judgment of 12 June 2003, para. 80.

${ }^{40}$ ECJ, Joined Cases 404 \& 656/15 PPU, Aranyosi and Căldăraru v. Generalstaatsanwaltschaft Bremen, ECLI:EU: C:2016:198, Judgment of 5 Apr. 2016; ECJ, Case 5-78/16 PPU, C.K. and Others v. Republika Solvenija, ECLI:EU: C:2017:127, Judgment of 16 Feb. 2017; Koen Lenaerts, La vie après l'avis: Exploring the Principle of Mutual (Yet Not Blind) Trust, 54 Common MKT. L. Rev. 805, 805-40 (2017).
} 
third-country national or the extradition of an EU citizen to a third country where such expulsion or such extradition would give rise to inhuman or degrading treatment. ${ }^{41}$

Third, regarding fundamental rights that may be subject to limitations, such as the right to respect for private life and the right to effective judicial protection, the essence of those rights is only compromised where the limitation in question empties those rights of their content or calls their very existence into question. To put it in the CJEU's own words, respect for the essence of a fundamental right means that that right "is not called into question as such." 42

That point can be illustrated by reference to the differences between, on the one hand, the limitations at issue in Schrems and, on the other hand, those that were examined in Digital Rights Ireland and Tele2 Sverige. In Schrems, the limitations on the right to respect for private life of data subjects were particularly drastic. In respect of the US public authorities, there was simply no privacy as those authorities could have unlimited access to the content of all the personal data transferred from the EU to the US. Furthermore, the limitation at issue in that case was not only extremely intense but also overwhelmingly broad.

In Digital Rights Ireland and Tele2 Sverige, the CJEU found, respectively, that the Data Retention Directive and the national legislation at issue imposed a serious limitation on the right to respect for private life in so far as, for the purpose of fighting serious crime, they provided for the retention of metadata. Nevertheless, those measures did not compromise the essence of that fundamental right because they did not permit retention of the content of electronic communications. ${ }^{43}$ In Digital Rights Ireland, the CJEU added that the essence of the right to protection of personal data was not compromised either. That Directive laid down certain principles of data protection and data security according to which Member States were obliged to ensure that appropriate technical and organizational measures were adopted to prevent the accidental or unlawful destruction and accidental loss or alteration of data. ${ }^{44}$ Thus, the limitations at issue in Digital Rights Ireland and Tele2 Sverige were less intense than those at issue in Schrems.

Similarly, in its Opinion 1/15 on the EU-Canada PNR Agreement, the CJEU found that the envisaged agreement constituted a serious limitation on the exercise of the right to respect for private life and of the right to protection of personal data, because it provided for the transfer of the personal data of air passengers travelling between Canada and the EU to the competent Canadian authority. Within the framework of the fight against terrorist offenses and serious transnational crime, that agreement also provided for the use of those data-that is to say, their retention and sharingby other Canadian authorities, those of the Member States, Europol, and Eurojust and even authorities of third-countries. ${ }^{45}$ Yet, the envisaged agreement did not compromise the essence of the right

\footnotetext{
${ }^{41}$ Article 19(2) of the Charter states that "[n]o one may be removed, expelled or extradited to a State where there is a serious risk that he or she would be subjected to the death penalty, torture or other inhuman or degrading treatment or punishment." See ECJ, Case C-562/13, Centre public d'action sociale d'Ottignies-Louvain-La_neuve v. Abdida, ECLI:EU:C:2014:2453, Judgment of 18 Dec. 2014, para. 48; ECJ, Case C-353/16, MP v. Secretary of State for the Home Department, ECLI:EU: C:2018:276, Judgment of 24 Apr. 2018, para. 43; ECJ, Case C-182/15, Petruhhin v. Latvijas Republikas Ģenerālprokuratūra, ECLI:EU:C:2016:630, Judgment of 6 Sept. 2016, para. 58.

${ }^{42}$ Regarding the principle of $n e$ bis in idem enshrined in Article 50 of the Charter, see ECJ, Case C-524/15, Menci, ECLI:EU: C:2018:197, Judgment of 20 Mar. 2018, para. 43; ECJ, Case C-537/16, Garlsson Real Estate and Others v. Commissione Nazionale per la Società e la Borsa, ECLI:EU:C:2018:193, Judgment of 20 Mar. 2018, para. 45. As to the right to vote in elections to the European Parliament enshrined in Article 39(2) of the Charter, see ECJ, Case C-650/13, Delvigne v. Commune de Lesparre Médoc, ECLI:EU:C:2015:648, Judgment of 6 Oct. 2015, para. 48. As to the principle of non-discrimination, see ECJ, Case C-528/13, Léger v. Ministre des Affaires sociales and Others, ECLI:EU:C:2015:288, Judgment of 29 Apr. 2015, para. 54 (regarding sexual orientation); Fries, Case C-190/16 at para. 38 (regarding age).

${ }^{43}$ Digital Rights Ireland, Joined Cases 293 \& 594/12 at para. 39; Tele2 Sverige AB, Joined Cases 203 \& 698/15 at para. 101.

${ }^{44}$ Digital Rights Ireland, Joined Cases 293 \& 594/12 at para. 40. In relation to Tele2 Sverige, see Opinion of Advocate General Saugmandsgaard Øe at paras. 158-59, Joined Cases 203 \& 698/15, Tele2 Sverige and Sec'y of State for the Home Dept. (Dec. 21, 2016), http://curia.europa.eu/juris/liste.jsf?num=C-203/15. In his view, the national legislation at issue provided for similar safeguards.

${ }^{45}$ ECJ, Opinion 1/15, ECLI:EU:C:2017:592, Judgment of 26 July 2017, paras. 124-25 [hereinafter EU-Canada PNR Agreement].
} 
to respect for private life given that the information to which those authorities had access was limited to certain aspects relating to air travel between Canada and the EU. Nor did that agreement compromise the essence of the right to protection of personal data, because it limited the purposes for which PNR data may be processed and laid down rules intended to ensure, inter alia, the security, confidentiality, and integrity of the data, and to protect them against unlawful access and processing. ${ }^{46}$

A joint reading of those judgments and of Opinion 1/15 suggests that, in order to determine whether a measure compromises the essence of a fundamental right, one must not only examine the intensity, but also the extent, of the limitation at issue. A measure that limits the exercise of certain aspects of a fundamental right, leaving others untouched, or that only applies in a specific set of circumstances regarding the individual conduct of the person concerned, is not such as to compromise the essence of that fundamental right. The case law of the CJEU appears to confirm such a reading. Three further examples may illustrate that point.

In $N$., the referring court called into question the compatibility with the Charter of a provision of the Reception Directive that empowers the Member States to detain an applicant for international protection when national security or public order ("ordre public") so requires. ${ }^{47}$ After finding that such a provision limited the right to liberty of those applicants and that the limitation at issue was provided for by law, the CJEU found that the essence of the right to liberty was not compromised. This was because that provision

does not render the guarantee of that right less secure and [because] the power that it confers on Member States enables them to detain an applicant only on the basis of his [or her] individual conduct and under the exceptional circumstances referred to in the same provision, those circumstances also being circumscribed by [other] conditions set out [in] the [Reception Directive] .... ${ }^{48}$

Likewise, in Delvigne, French legislation precluded nationals who had been convicted of a serious criminal offense from exercising their right to vote in elections to the European Parliament, a right guaranteed by Article 39(2) of the Charter. Whilst constituting a limitation on the exercise of that right, such legislation did not compromise its essence. The CJEU reasoned that "[such a] limitation [did] not call into question that right as such, since it [had] the effect of excluding certain persons, under specific conditions and on account of their conduct, from those entitled to vote in elections to the Parliament, as long as those conditions [were] fulfilled." ${ }^{4}$

In the same way, in Menci, the CJEU was asked whether Article 50 of the Charter had to be interpreted as precluding national legislation in accordance with which criminal proceedings may be brought against a person for failing to pay value added tax (VAT) due within the time limit stipulated by law, even though that person had already been made subject, in relation to the same acts, to a final administrative penalty. Similarly, in Garlsson, the Italian legislation at issue provided for the possibility of bringing administrative proceedings against a person with respect to unlawful conduct consisting of market manipulation for which the same person had already been convicted. ${ }^{50}$ In both cases, the CJEU found that such a duplication of proceedings and penalties

\footnotetext{
${ }^{46} I d$. at para. 150 .

${ }^{47}$ See Directive 2013/33, of the European Parliament and of the Council of 26 June 2013 Laying Down Standards for the Reception of Applicants for International Protection, 2013 O.J. (L 180) 96 (EU), art. 8(3)(e).

${ }^{48}$ ECJ, Case C-601/15 PPU, J. N. v. Staatssecretaris van Veiligheid en Justitie, ECLI:EU:C:2016:84, Judgment of 15 Feb. 2016 , para. 52. See also ECJ, Case C-18/16, K. v. Staatssecretaris van Veiligheid en Justitie, ECLI:EU:C:2017:680, Judgment of 14 Sept. 2017, para. 35.

${ }^{49}$ Delvigne, Case C-650/13 at para. 48.

${ }^{50}$ Menci, Case C-524/15; Garlsson Real Estate, Case C-537/16.
} 
constituted a limitation on the ne bis in idem principle guaranteed by Article 50 of the Charter. ${ }^{51}$ Nevertheless, the essence of that fundamental right was not compromised given that the legislation at issue allowed "such a duplication ... only under conditions which are exhaustively defined, thereby ensuring that the right guaranteed by Article 50 is not called into question as such." ${ }^{\prime 2}$

\section{The Essence of Fundamental Rights and the Principle of Proportionality}

It follows from Schrems that the essence of a fundamental right places an absolute limit on the limitations that may be imposed on the exercise of that fundamental right. Where a measure compromises the essence of a fundamental right, it is per se incompatible with the Charter, without there being a need to carry out a balancing exercise between competing interests.

It is true that there is some overlap between the concept of the essence of a fundamental right and the principle of proportionality. First, where a measure complies with the principle of proportionality, such a measure may also be regarded as respecting the essence of the fundamental right in question. Indeed, it is simply impossible for a measure to impose a proportionate limitation on the exercise of a fundamental right, whilst depriving that right of its essence. Second, and conversely, where a measure violates the essence of a fundamental right, such a measure automatically constitutes a violation of the principle of proportionality.

However, this is where the overlap ends, because a measure may respect the essence of a fundamental right and yet still violate the principle of proportionality. This can be seen in cases such as Digital Rights Ireland and Tele2 Sverige.

In Digital Rights Ireland, the CJEU noted that the Data Retention Directive imposed a limitation on the rights enshrined in Articles 7 and 8 of the Charter that was "particularly serious," 53 because that Directive required the retention of metadata in connection with "all persons and all means of electronic communication as well as all traffic data without any differentiation, limitation or exception being made in the light of the objective of fighting against serious crime." ${ }^{54}$ After finding that the essence of the right to respect for private life and that of the right to protection of personal data were not compromised, the CJEU went on to carry out a proportionality assessment. It held that the retention of metadata in connection with electronic communications was an appropriate means of attaining the objective pursued by the Data Retention Directive - to fight serious crime. As such, retention was indeed a valuable tool for criminal investigations. Yet, regarding the necessity of the measure, the CJEU held that, since that Directive entailed a wide-ranging and particularly serious interference with the fundamental right to private life, "derogations and limitations in relation to the protection of personal data must apply only in so far as is strictly necessary." 55 This meant that when adopting the Data Retention Directive, the EU legislator was under "the obligation to lay down clear and precise rules governing the extent of the interference with the fundamental rights enshrined in Articles 7 and 8 of the Charter." ${ }^{2}$ The CJEU considered that the EU legislator had failed to do so. ${ }^{57}$

Similarly, in Tele2 Sverige, the CJEU held that, whilst the Swedish legislation at issue did not compromise the essence of the right to respect for private life, it exceeded the limits of what was strictly necessary to attain the legitimate objective of fighting serious crime. This was because, like the Data Retention Directive, the Swedish legislation imposed a serious limitation on that

\footnotetext{
${ }^{51}$ Menci, Case C-524/15 at para. 39; Garlsson Real Estate, Case C-537/16 at para. 41.

${ }^{52}$ Menci, Case C-524/15 at para. 43; Garlsson Real Estate, Case C-537/16 at para. 45.

${ }^{53}$ Digital Rights Ireland, Joined Cases 293 \& 594/12 at para. 37.

${ }^{54} I d$. at para. 57.

${ }^{55} \mathrm{Id}$. at para. 52 .

${ }^{56} I d$. at para. 65.

${ }^{57} \mathrm{Id}$. at paras. $66-69$.
} 
fundamental right, ${ }^{58}$ as it provided for a general and indiscriminate retention of all the traffic and location data of all subscribers and registered users relating to all means of electronic communication. Further, it imposed on providers of electronic communications services an obligation to retain those data systematically and continuously, with no exceptions. Where national legislation provides for the retention of traffic and location data as a means of preventing serious crime, compliance with the principle of proportionality is subject to both procedural and substantive conditions. Procedurally, it must lay down clear and precise rules governing the scope and application of data retention and impose minimum safeguards that guarantee effective judicial protection. ${ }^{59}$ Substantively, it must establish a link between the data to be retained and the objective pursued. ${ }^{60}$

As AG Saugmandsgaard Øe observed in his Opinion in Ministerio Fiscal, it follows from the judgments of the CJEU in Digital Rights Ireland and Tele2 Sverige that compliance with the principle of proportionality requires "[the] establishment of a link between the seriousness of the interference found and the seriousness of the reason that could justify the interference." ${ }^{61}$ In Ministerio Fiscal, the CJEU endorsed that observation explicitly: ${ }^{62}$ Only the fight against serious crime may justify a serious interference. ${ }^{63}$ Conversely, the objective of fighting crime generally may justify an interference that is not serious. ${ }^{64}$ In the case at hand, the question was whether access by the police to data for the purposes of identifying the owners of SIM cards activated by a stolen mobile telephone-such as their surnames, forenames and, if need be, addresses-constituted a serious interference with their rights to respect for private life and to protection of personal data. The CJEU replied in the negative, given that those data only enabled the police to establish the identity of the owners of those SIM cards, but did not cover the communications carried out with a stolen mobile phone. In other words, the interference was not serious, because "[ $t$ ] hose data do not therefore allow precise conclusions to be drawn concerning the private lives of the persons whose data is concerned." ${ }^{65}$ Accordingly, EU law did not preclude the national court from authorizing the police to have access to those data for the purposes of fighting crime generally. ${ }^{66}$

From a methodological perspective, the case law of the CJEU reflects the fact that that court will first examine whether the measure in question respects the essence of the fundamental rights at stake and will only carry out a proportionality assessment if the answer to that first question is in the affirmative. ${ }^{67}$

\footnotetext{
${ }^{58}$ Tele2 Sverige $A B$, Joined Cases $203 \& 698 / 15$ at para. 100.

${ }^{59} I$. at para. 109.

${ }^{60} \mathrm{Id}$. at para. 110 .

${ }^{61}$ Opinion of Advocate General Saugmandsgaard Øe at para. 82, Case C-207/16, Ministerio Fiscal (Oct. 2, 2018), http:// curia.europa.eu/juris/liste.jsf?num=C-207/16.

${ }^{62}$ ECJ, Case C-207/16, Ministerio Fiscal, ECLI:EU:C:2018:788, Judgment of 2 October 2018, para. 55.

${ }^{63} \mathrm{Id}$. at para. 56.

${ }^{64} I d$. at para. 57.

${ }^{65} \mathrm{Id}$. at paras. $59-60$.

${ }^{66} \mathrm{Id}$. at para. 62.

${ }^{67}$ See, e.g., Sky Österreich, Case C-283/11 at paras. 48-50; Digital Rights Ireland, Joined Cases 293 \& 594/12 at paras. 39-45; ECJ, Case C-129/14 PPU, Spasic, ECLI:EU:C:2014:586, Judgment of 27 May 2014, paras. 56-60; Léger, Case C-528/13 at paras. 51-55; Delvigne, Case C-650/13 at paras. 46-49; ECJ, Case C-157/14, Société Neptune Dist. v. Ministre de l'Économie et des Finances, ECLI:EU:C:2015:823, Judgment of 17 Dec. 2015, paras. 68-76; N., Case C-601/15 PPU at paras. 50-54; ECJ, Case C-477/14, Pillbox 38 v. Sec'y of State for Health, ECLI:EU:C:2016:324, Judgment of 4 May 2016, paras. 160-62; ECJ, Case C-547/14, Philip Morris Brands and Others v. Sec'y of State for Health, ECLI:EU:C:2016:325, Judgment of 4 May 2016, paras. 149-53; ECJ, Joined Cases 439 \& 488/14, SC Star Storage SA and Others v. Institutul Național de Cercetare-Dezvoltare în Informatică (ICI) and Others, ECLI:EU: C:2016:688, paras. 49-51; ECJ, Case C-201/15, AGET Iraklis v. Y pourgos Ergasias, Koinonikis Asfalisis kai Koinonikis Allilengyis, ECLI:EU:C:2016:972, Judgment of 21 Dec. 2016, paras. 82- 89; Tele2 Sverige AB, Joined Cases 203 \& 698/15 at paras. 101-07; ECJ, Case C-258/14, Florescu and Others v. Casa Județeană de Pensii Sibiu and Others, ECLI:EU:2017:448, Judgment of 13 June 2017 , paras. 53- 57; Fries, Case C-190/16 at paras. 36-39; K., Case C-18/16 at paras. 34-37; ECJ, Case C-73/16, Puškár v Finančné riaditel'stvo Slovenskej republiky and Kriminálny úrad finančnej správy, ECLI:EU:C:2017:725, Judgment of 27 Sept. 2017, paras. 62-65; ECJ, Case C-380/16, Comm'n v. Germany, ECLI:EU:C:2018:76, Judgment of 8 Feb. 2018, paras. 65-71; Menci, Case C-524/ 15 at paras 43-46; Garlsson Real Estate, Case C-537/16 at paras. 45-48.
} 
The application of that method of analysis is not simply empty formalism, but rather seeks to emphasize the point that the essence of a fundamental right is absolute and not subject to balancing.

Otherwise, if the CJEU were to examine first whether the measure in question complies with the principle of proportionality, the concept of the essence of fundamental rights would lose both its importance and its autonomous nature. On the one hand, once it is held that the contested measure complies with the principle of proportionality, the result of the respect-for-the-essence test becomes obvious. On the other hand, once it is established that the contested measure violates the principle of proportionality, the application of the respect-for-the-essence-test becomes devoid of purpose because the measure has already been found to be incompatible with the Charter. It might also give rise to inconsistencies where the CJEU subsequently finds that the measure in question also compromises the essence of a fundamental right. This is because the CJEU would have undertaken a balancing exercise that should not have been undertaken in the first place.

It is worth noting that the case law of the ECtHR has not always followed the method of analysis employed by the CJEU but has rather, in the past, incorporated the concept of the essence of a fundamental right into a proportionality assessment. ${ }^{68}$ Moreover, in Ezz and Others $v$ Council, it was only after having found that the freezing of assets of the persons subject to EU restrictive measures constituted a proportionate limitation on those persons' right to property, that the GC examined the question of whether those measures respected the essence of that fundamental right. Unsurprisingly, the GC answered that question in the affirmative. ${ }^{69}$ Nevertheless, for the reasons mentioned above, this Article respectfully submits that this manner of proceeding is not correct, as it reflects neither the absolute nature of the essence of fundamental rights, nor the logic underpinning Article 52(1) of the Charter.

\section{The Essence of Fundamental Rights and the Question of Horizontal Direct Effect}

Just like certain Treaty provisions and general principles of EU law, the CJEU has held that a fundamental right enshrined in a provision of the Charter may produce horizontal direct effect, provided that such a Charter provision is sufficient in itself and does not need to be made more specific by other provisions of EU or national law to confer on individuals a right on which they may rely as such. Accordingly, such a right is unconditional and mandatory in nature, applying not only to the action of public authorities, but also in disputes between private parties. ${ }^{70}$ In that regard, the CJEU has noted that Articles 21, 31(2), and 47 of the Charter may produce horizontal direct effect. ${ }^{71}$

\footnotetext{
${ }^{68}$ See, e.g., Brkan, supra note 12, at 361-63. See also Gregoire Webber, Proportionality and Absolute Rights, in Proportionality: New Frontiers, New Challenges 51-74 (Vicki Jackson \& Mark Tushnet eds., 2017) (arguing that "either absolute rights are an exception to proportionality analysis or absolute rights are the result of proportionality analysis"). Similarly, the same two opposing views may be put forward in respect of the principle of proportionality and the concept of essence.

${ }^{69} \mathrm{Ezz}$, Case T-256/11 at para. 209.

${ }^{70}$ Koen Lenaerts \& Jose A. Gutiérrez-Fons, The European Court of Justice as the Guardian of the Rule of "EU Social Law," in A European Social Union: After the Crisis 446 (Frank Vandenbroucke, Catherine Barnard \& Geert De Baere eds., 2017). It is true that, unlike the EU institutions, bodies, offices, and agencies, as well as the Member States-but only when implementing EU law-private parties are not explicitly mentioned in Article 51(1) of the Charter amongst the Charter's addressees. That absence might support the view that the Charter as a whole is unable to produce horizontal direct effect. Nevertheless, whilst some judgments implicitly discarded that view-ECJ, Case C-414/16, Ergenberger v. Evangelisches Werk für Diakonie und Entwicklung eV, ECLI:EU:C:2018:527, Judgment of 17 Apr. 2018, para. 76 - the CJEU did so explicitly in ECJ, Joined Cases 569 \& 570/16, Bauer and Willmeroth, ECLI:EU:C:2018:871, Judgment of 6 Nov. 2018, paras. 87-90; ECJ, Case C-684/16, Max-Planck-Gesellschaft zur Förderung der Wissenschaften v. Shimizu, ECLI:EU:C:2018:874, Judgment of 6 Nov. 2018, paras. 76-79.

${ }^{71}$ See ECJ, Case C-555/07, Kücükdeveci v. Swedex GmbH \& Co., ECLI:EU:C:2010:21, Judgment of 19 Jan. 2010; ECJ, Case C-441/14, DI v. Estate of Rasmussen, ECLI:EU:C:2016:278, Judgment of 19 Apr. 2016; Egenberger, Case C-414/16; ECJ, Case C-68/17, IR v. JQ, ECLI:EU:C:2018:696, Judgment of 11 Sept. 2018; Bauer and Willmeroth, Joined Cases 569 \& 570/16; MaxPlanck-Gesellschaft, Case C-684/16.
} 
In respect of the rights recognized in the Charter that satisfy that proviso, an a maiore ad minus argument militates in favor of their essence producing horizontal direct effect.

By contrast, in Association de médiation sociale, the CJEU found that Article 27 of the Charter, entitled "Workers' right to information and consultation within the undertaking," does not produce such an effect. It found, in that regard, that "for [Article 27 of the Charter] to be fully effective, it must be given more specific expression in [EU] or national law."72

At this point, one may draw a distinction between two types of situation.

\section{Beyond the Essence}

On the one hand, there are Charter provisions that contain rights which may produce horizontal direct effect beyond the scope of their essence. This is because non-essential elements of those rights are sufficient in themselves and do not need to be made more specific by other provisions of EU or national law in order to confer on individuals a right on which they may rely as such. Therefore, those elements are mandatory and unconditional in nature and are fully effective at primary EU level. Accordingly, those rights may be relied upon in a dispute between private parties with a view to setting aside a national measure that, whilst not compromising the essence of those rights, constitutes a disproportionate limitation on their exercise. This appears to be the case of the rights enshrined in Articles 21 and 47 of the Charter. The seminal ruling of the CJEU in Egenberger illustrates this point. ${ }^{73}$

In that case, Ms. Vera Egenberger brought a claim seeking compensation against the Evangelisches Werk, a charitable organization of the German Protestant Church, contending that she suffered discrimination on grounds of religion during a recruitment procedure. The parties in the main proceedings agreed that the applicant had been the subject of a difference of treatment given that her job application was dismissed because she was of no denomination. ${ }^{74}$ Yet, the Evangelisches Werk argued that the difference of treatment was justified by the churches' right to self-determination. ${ }^{75}$

Thus, in Egenberger, the CJEU was asked to interpret Article 4(2) of Directive 2000/78, ${ }^{76}$ a provision that states that:

[A] difference of treatment based on a person's religion or belief shall not constitute discrimination where, by reason of the nature of these activities or of the context in which they are carried out, a person's religion or belief constitute a genuine, legitimate and justified occupational requirement, having regard to the organization's ethos. ${ }^{77}$

The referring court asked, inter alia, whether Article 4(2) of Directive 2000/78 could be interpreted as meaning that a church or other organization whose ethos is based on religion or belief may itself determine authoritatively the occupational activities for which religion constitutes a genuine, legitimate, and justified occupational requirement, with regard to the ethos of the church or organization. The referring court pointed out that under German law, judicial review was limited to a "plausibility review," meaning that labor courts could not second-guess the activities that a church itself described as "close to" or "remote from" the proclamation of the church's message. ${ }^{78}$ That said, at the hearing the German government criticized the analysis of German

\footnotetext{
${ }^{72}$ ECJ, Case C-176/12, Association de médiation sociale v. Union locale des syndicats CGT and Others, ECLI:EU:C:2014:2, Judgment of 15 Jan. 2014, para. 45.

${ }^{73}$ See also DI, Case C-441/14; IR, Case C-68/17.

${ }^{74}$ Egenberger, Case C-414/16 at para. 43.

${ }^{75} I d$. at para. 28 .

${ }^{76}$ Council Directive 2000/78, of 27 November 2000 Establishing a General Framework for Equal Treatment in Employment and Occupation, 2000 O.J. (L 303) 16 (EC).

${ }^{77} I d$. (emphasis added).

${ }^{78}$ Egenberger, Case C-414/16 at paras. $31-32$.
} 
law contained in the order for reference, noting that the plausibility review was complemented by an overall assessment of the relevant circumstances of the case in light of which labor courts could engage in a balancing exercise of competing interests. ${ }^{79}$

Be that as it may, the CJEU replied in the negative to the question referred, holding that an independent authority — and ultimately a national court — had to ensure effective judicial review by examining whether the difference in treatment at issue complied with the criteria set out in Article 4(2) of Directive 2000/78. ${ }^{80}$

On the assumption that the interpretation of German law put forward by the referring court was accurate, one could argue that German law imposed a disproportionate limitation on the exercise of the right to effective judicial protection, enshrined in Article 47 of the Charter and as given concrete expression in Article 4(2) of Directive 2000/78. Nevertheless, German law did not compromise the essence of that right because some degree of judicial scrutiny was still possible for employees who claimed to be the victims of discrimination. As to Article 21 of the Charter, the essence of the prohibition of all discrimination on grounds of religion was not compromised either. The misapplication of the criteria laid down in Article 4(2) of Directive 2000/78 meant that the national legislator had failed to strike the right balance between the competing interests embedded in that provision. ${ }^{81}$ Yet, such a failure did not call that prohibition into question as such. ${ }^{82}$ Given that Articles 21 and 47 of the Charter may produce horizontal direct effect in a situation such as that at issue in the main proceedings, it follows from the ruling of the CJEU in Egenberger that a national court must set aside a national provision that, whilst imposing a disproportionate limitation on the exercise of the rights enshrined in those two provisions of the Charter, does not compromise their essence. ${ }^{83}$

\section{Just the Essence}

On the other hand, there are also fundamental rights whose essence may produce horizontal direct effect, but whose non-essential elements may not. This is because, unlike their essence, for those non-essential elements to be fully effective, the national or EU legislator must take action. Accordingly, only measures compromising the essence of those rights may be set aside. This point

\footnotetext{
${ }^{79}$ Opinion of Advocate General Tanchev at paras. 63-65, Case C-414/16, Egenberger (Apr. 17, 2018), http://curia.europa. eu/juris/liste.jsf?num $=\mathrm{C}-414 / 16$.

${ }^{80}$ Egenberger, Case C-414/16 at para. 55.

${ }^{81} I d$. at para. 51 .

The objective of Article 4(2) of Directive 2000/78 is thus to ensure a fair balance between the right of autonomy of churches and other organisations whose ethos is based on religion or belief, on the one hand, and, on the other hand, the right of workers, inter alia when they are being recruited, not to be discriminated against on grounds of religion or belief, in situations where those rights may clash.

In the same way, in $I R$, the CJEU found that respect for "the sacred and indissoluble nature of religious marriage" was not necessary in order for a limited liability company belonging to the Catholic Church to promote its own ethos, in respect of the occupational activities carried out by one of its employees-for example, a doctor who was the Head of the Internal Medicine Department in one of the hospitals operated by such a limited liability company. See IR, Case C-68/17 at para. 5. See also, DI, Case C-441/14 at para. 26. In that case, the CJEU found that both Directive 2000/78 and the principle of non-discrimination on grounds of age, enshrined in Article 21 of the Charter, opposed the Danish legislation at issue pursuant to which workers who were eligible for an old-age pension from their employer under a pension scheme which they had joined before attaining the age of 50 years could not, on that ground alone, claim a severance allowance aimed at assisting workers with more than twelve years of service in the undertaking in finding new employment. In so doing, the CJEU referred to its previous findings in ECJ, Case C-499/08, Ingeniørforeningen i Danmark v. Region Syddanmark, ECLI:EU:C:2010:600, Judgment of 12 Oct. 2010, paras. 47-49, where it had ruled that the same Danish legislation did not comply with the principle of proportionality as it went beyond what was necessary to attain the objectives pursued.

${ }^{82}$ Egenberger, Case C-414/16 at paras. $80-81$.

${ }^{83} \mathrm{See}$ Bundesarbeitsgericht [BAG] [Federal Labor Court] Oct. 26, 2018, 8 AZR 501/14, ECLI:DE: BAG:2016:170316.B.8AZR501.14A.0.
} 
is illustrated by the rulings of the CJEU in Bauer and Willmeroth and Max-Planck. The facts of those cases are as follows.

In joined cases Bauer and Willmeroth, a public and a private employer, respectively, refused to pay the widows of deceased workers an allowance in lieu of the paid annual leave not taken by their spouses before their deaths. In so doing, those employers relied on German legislation, according to which, when the employment relationship is terminated by the death of the worker, the entitlement to paid annual leave is lost retroactively without conferring any entitlement to an allowance in lieu of outstanding paid annual leave.

After recalling its previous case law, the CJEU ruled that Article 7 of Directive 2003/88 and Article 31(2) of the Charter had to be interpreted as opposing such legislation. ${ }^{84}$ In so doing, the CJEU stressed the fact that:

The [retroactive] loss of a worker's acquired right to paid annual leave or his corresponding right to payment of an allowance in lieu of leave not taken upon termination of the employment relationship, without the worker having actually had the opportunity to exercise that right to paid annual leave, would undermine the very substance of that right. ${ }^{85}$

In Max-Planck, the question was whether Article 7 of Directive 2003/88 and Article 31(2) of the Charter had to be interpreted as precluding legislation that provided for the automatic loss of an allowance in lieu of untaken paid annual leave at the end of the employment relationship, where the worker had not sought to exercise his right to paid annual leave during the reference period. The CJEU replied in the affirmative. It held that such loss can never be automatic but may only take place where it has been demonstrated that the employer put the worker in a position that enabled him or her to exercise that right effectively. ${ }^{86}$ Again, reproducing the passage mentioned in the previous paragraph ${ }^{87}$ the CJEU also found that the legislation at issue in the main proceedings compromised the essence of the right to paid annual leave. ${ }^{88}$

Next, the CJEU recalled that only where it is impossible to interpret the relevant legislation in light of Article 7 of Directive 2003/88 and Article 31(2) of the Charter, may the national court examine the question of direct effect. ${ }^{89}$ In Bauer, the employer was the City of Wuppertal. This meant that, since Article 7 of Directive 2003/88 was sufficiently precise and unconditional to produce direct effect, ${ }^{90}$ the widow of the deceased employee could rely on that provision with a view to setting aside conflicting legislation. ${ }^{91}$ However, in Willmeroth and Max-Planck, this was not the case as the employers were, respectively, a private undertaking and a non-profit-making organization governed by private law. In accordance with settled case law, this meant that Article 7 of Directive 2003/88 could not be relied upon against those employers. ${ }^{92}$

Logically, the question was whether Article 31(2) of the Charter could produce horizontal direct effect. Regarding the "very existence" of the right to paid annual leave, the CJEU replied in the affirmative. First, as to the origins of the right to paid annual leave, the CJEU stressed the fact that neither Directive 93/104 nor Directive 2003/88 established that right, ${ }^{93}$ but that it "is itself mainly derived both

\footnotetext{
${ }^{84}$ Directive 2003/88, of the European Parliament and of the Council of 4 November 2003 Concerning Certain Aspects of the Organisation of Working Time, 2003 O.J. (L 299) 9 (EC).

${ }^{85}$ Bauer and Willmeroth, Joined Cases $569 \& 570 / 16$ at para. 49 (emphasis added).

${ }^{86}$ Max-Planck-Gesellschaft, C-684/16 at paras. $40-45$.

${ }^{87} I d$. at para. 26.

${ }^{88} I d$. at para. 61 .

${ }^{89}$ Bauer and Willmeroth, Joined Cases 569 \& 570/16 at paras. 65-69; Max-Planck-Gesellschaft, C-684/16 at paras. 57-60.

${ }^{90}$ Bauer and Willmeroth, Joined Cases $569 \& 570 / 16$ at paras 71-73; Max-Planck-Gesellschaft, C-684/16 at para. 68.

${ }^{91}$ Bauer and Willmeroth, Joined Cases $569 \& 570 / 16$ at para. 75.

${ }^{92}$ Id. at paras. 76-78; Max-Planck-Gesellschaft, C-684/16 at paras. 66-68.

${ }^{93}$ Directive 93/104, of 23 November 1993 Concerning Certain Aspects of the Organization of Working Time, 1993 O.J. (L 307) 18 (acting as the predecessor of Directive 2003/88, which repealed it).
} 
from instruments drawn up by the Member States at EU level ... and from international instruments on which the Member States have cooperated or to which they are party." ${ }^{\prime 4}$ Second, as an essential principle of EU social law, that right is mandatory in nature and is formed by two essential components - for example, the right to paid annual leave "as such" and the right to an allowance in lieu of paid annual leave not taken where the employment relationship is terminated. ${ }^{95}$ Third, and last, the CJEU noted that Article 31(2) of the Charter is framed in compulsory terms- "[e]very worker" has "the right" to "an annual period of paid leave" — and that, unlike other provisions of the Charter-such as Article 27-it contains no reference to "the conditions provided for by Union law and national laws and practices" under which that right is to be exercised. Accordingly, the CJEU held that "Article 31(2) of the Charter, reflects the essential principle of EU social law from which there may be derogations only in compliance with the strict conditions laid down in Article 52(1) of the Charter and, in particular, with the essence of the fundamental right to paid annual leave." 96

As regards to the "very existence" of the right to paid annual leave-an expression that, in the light of Schrems, corresponds to the essence of that right- the CJEU noted that the Charter provision stating the essence of such right is sufficient in itself and does not need to be made more specific by other provisions of EU or national law in order to confer on individuals a right on which they may rely as such. ${ }^{97}$ Accordingly, the essence of such a right is unconditional and mandatory in nature, applying not only to the action of public authorities, but also in disputes between private parties. Secondary EU law or, as the case may be, national law, are called upon only to determine non-essential elements of that right. ${ }^{98}$ Thus, in the light of the rulings of the CJEU in Bauer and Willmeroth and Max-Planck, one may argue that Article 31(2) of the Charter may be relied upon where a national measure compromises the essence of the right to paid annual leave by bringing about the loss of that right. Conversely, that is not the case with respect to nonessential elements of that right, such as the precise duration of annual leave and, where appropriate, certain conditions under which that right is to be exercised.

\section{Concluding Remarks}

As an absolute limit on limitations, the essence of a fundamental right defines a sphere of liberty that must always remain free from interference.

In the case of fundamental rights that are absolute - such as the prohibition of inhuman or degrading treatment - the content of such rights is "all essence," meaning that no limitation may be imposed on their exercise.

Regarding fundamental rights whose exercise may be subject to limitations, a measure that respects the essence of such rights does not call them into question as such. It follows from the case law of the CJEU that the essence of a fundamental right is not compromised where the measure in question limits the exercise of certain aspects of such a right, leaving others untouched, or applies in a specific set of circumstances with regard to the individual conduct of the person concerned. Conversely, in order for an EU or national measure to compromise the essence of a fundamental right, such a measure must constitute a particularly intense and broad limitation on the exercise of such a right.

\footnotetext{
${ }^{94}$ Bauer and Willmeroth, Joined Cases 569 \& 570/16 at para. 81; Max-Planck-Gesellschaft, C-684/16 at para. 70. In those judgments, the CJEU mentioned the Community Charter of the Fundamental Social Rights of Workers and the European Social Charter, both of which are mentioned in Article 151 TEU. In addition, it also mentioned Convention No. 132 of the International Labour Organisation of 24 June 1970 concerning Annual Holidays with Pay (revised).

${ }^{95}$ Bauer and Willmeroth, Joined Cases 569 \& 570/16 at para. 83; Max-Planck-Gesellschaft, C-684/16 at para. 72.

${ }^{96}$ Bauer and Willmeroth, Joined Cases 569 \& 570/16 at para. 84; Max-Planck-Gesellschaft, C-684/16 at para. 73.

${ }^{97}$ Bauer and Willmeroth, Joined Cases 569 \& 570/16 at para. 85; Max-Planck-Gesellschaft, C-684/16 at para. 74.

${ }^{98}$ Bauer and Willmeroth, Joined Cases 569 \& 570/16 at para. 85; Max-Planck-Gesellschaft, C-684/16 at para. 74.
} 
The fact that the concept of "the essence of a fundamental right" is only compromised in extreme cases is a good thing. Because no interference with that sphere of liberty may be justified, the CJEU must proceed with caution when defining the circumstances under which the essence of a fundamental right is compromised. A broad understanding of that concept would run the risk of transforming all rights recognized in the Charter into absolute rights, which is simply untenable in a democratic system of governance such as the EU where the balancing of competing interests occurs regularly.

Besides, in order to protect fundamental rights effectively, there is no need for such a broad understanding. This is because when it comes to applying the principle of proportionality to limitations on the exercise of fundamental rights, the CJEU does not confine itself to ascertaining whether the measure in question is manifestly inappropriate to attain the objectives it pursues. ${ }^{99}$ As the CJEU held in Digital Rights Ireland, the more extensive and serious an interference with fundamental rights is, the less discretion the EU legislator enjoys and the stricter judicial scrutiny will be. ${ }^{100}$ In light of Tele2 Sverige, the same applies to national legislatures.

Regardless of the dangers and challenges that we Europeans may face in the future, the concept of the essence of a fundamental right operates as a constant reminder that our core values are absolute and, as such, are not subject to balancing. In my view, the essence of fundamental right is the most fundamental bastion of liberty that the CJEU will never give up.

\footnotetext{
${ }^{99}$ See e.g., Koen Lenaerts \& Jose A. Gutiérrez-Fons, A Constitutional Perspective, in OXFORD PRINCIPLES OF EUROPEAN Union Law. Volume I: The European Union Legal Order, supra note 23, at 103, 116.

${ }^{100}$ Digital Rights Ireland, Joined Cases 293 \& 594/12 at paras. 47-48.
} 